Croft, D. N. (1970). Prescribers' fournal, 10, 14.

Croft, D. N., and Wood, P. H. N. (1967). British Medical fournal, 1, 137.

Cuddigan, J. H. P., Sweetland, C., and Croft, D. N. (1971). Rheumatology and Physical Medicine, 11, 36.

Parry, D. J., and Wood, P. H. N. (1967). Gut, 8, 301.

Rosner, I., Khalili-Varasteh, H., and Legros, J. (1971). VII European Rheumatology Congress. Abstract No. 45/1.

Schiller, K. F. R., Truelove, S. C., and Williams, D. G. (1970). British Medical fournal, $2,7$.
Scott, J. T., Porter, I. H., Lewis, S. M., and Dixon, A. St. J. (1961). Quarterly fournal of Medicine, 30, 167.

Sperryn, R. N., Nicholson, P. A., Parsons, V., and Hamilton, E. B. D. (1971). VII European Rheumatology Congress. Abstract No. 45/3.

Thompson, M., and Anderson, M. (1970). Rheumatology and Physical Medicine, Suppl., p. 104.

Valman, H. B., Parry, D. J., and Coghill, N. F. (1968). British Medical Fournal, 4,661.

Wood, P. H. N., Harvey-Smith, E. A., and Dixon, A. St. J. (1962). British Medical fournal, 1, 669.

\title{
Continuous Intragastric Milk Feeds in Infants of Low Birth Weight
}

\author{
H. B. VALMAN, C. D. HEATH, R. J. K. BROWN
}

British Medical fournal, 1972, 3, 547-550

\section{Summary}

In a feeding trial 66 infants of low birth weight received continuous intragastric milk feeds from the fourth hour of life, starting with $60 \mathrm{ml} / \mathrm{kg} / 24 \mathrm{hr}$ and reaching a maximum of $300 \mathrm{ml} / \mathrm{kg} / 24 \mathrm{hr}$ on the ninth day. Each infant received only full-strength milk, which was either expressed human breast milk or SMA-S26 (a proprietary low-protein adapted cows' milk) or half-cream Regal milk (partly-skimmed evaporated cows' milk). For various reasons 10 babies had to be withdrawn, and the final assessment was made on the 56 who completed the trial successfully.

Persistent vomiting was a problem in only four infants. In two of them the trial was continued after gastric lavage and in the other two vomiting stopped when the volume was reduced. Despite a careful search no evidence was found of aspiration of feeds in any infant. Continuous intragastric milk infusion was shown to be a safe method of feeding infants of low birth weight and SMA-S26 was almost as well tolerated as human milk. Because of the high-protein content of half-cream cows' milk preparations and the resultant high plasma amino-acid levels when they are given in these large volumes they should be avoided for this type of feeding although they produce better weight gains in the first week of life.

\section{Introduction}

The most important controllable factors determining the survival and normal development of the newborn infant weighing $2,500 \mathrm{~g}$ or less are adequate food (Drillien, 1964; Davies and Russell, 1968) and warmth (Buetow and Klein, 1964; Day et al., 1964; Daily et al., 1969). The optimum environmental temperatures for various birth weights have been carefully a sessed (Scopes and Ahmed, 1966; Hey and Katz, 1970) but the best method of feeding such small infants is still the subject of controversy.

Tube feeding is necessary for the very small infant because of the danger of aspiration consequent on the absence of normal sucking, swallowing, and cough reflexes. Movement of the diaphragm is easily impeded by gastric distension, so that inter-

\footnotetext{
Hackney Hospital, London E.9

H. B. VALMAN, M.R.C.P., D.C.H., Senior Registrar (Present appointment: Consultant Paediatrician, Northwick Park Hospital, Middlesex)

C. D. HEATH, M.D., M.R.C.P., Research Fellow (Present appointment: Medical Assistant, St. Thomas's Hospital, London S.E.1)

R. J. K. BROWN, F.R.C.P., D.C.H., Consultant Paediatrician
}

mittent tube feeds need to be of small volume and given at frequent intervals, and this is extravagant of nurses' time. It has been stated that a generous protein and energy intake is necessary to obtain optimal growth in infants of low birth weight (Gordon et al., 1947; Young et al., 1950; Davidson et al., 1967). One cannot say with certainty what is the optimal weight gain for these infants, but it should enable babies whose weight is "appropriate for dates" to return to their initial centiles within a few weeks and most babies "light for dates" to cross the lowest centile lines. This is not achieved by the energy intakes recommended by Gordon et al. (1947), (Babson, 1970), but the provision of an adequate energy intake with milk alone entails the administration of such large volumes that it has become popular to use concentrated feeds (Combes and Pratt, 1961). However, water balance is a primary consideration in infant feeding when the diet gives a high renal solute load, and concentrated feeds can be dangerous (Ziegler and Fomon, 1971).

Human milk is such a safe and well-tolerated feed that many paediatricians would prefer it for feeding small babies if there was an acceptable method of administering large volumes safely. The use of continuous intragastric drip feeding with expressed breast milk was suggested by D. Hilson (personal communication) in 1960 and was given a trial in the premature baby unit of this district hospital. The results were so satisfactory that it came to be used as a routine in the unit. Before advocating the widespread use of this type of feeding we thought it desirable to carry out a critical assessment of its safety. At the same time we decided to determine whether two other l'quid milks, a proprietary low-protein adapted cows' milk (SMA-S26) and a partly-skimmed evaporated cows' milk preparation (half-cream Regal), would prove satisfactory substitutes when human milk was in short supply.

\section{Patients and Methods}

Infants weighing between 1,000 and $2,100 \mathrm{~g}$ at birth entered the trial at the age of 4 hours. At first infants who developed signs of severe respiratory distress syndrome before 4 hours were given $10 \%$ dextrose with sodium bicarbonate by continuous intragastric drip and were therefore excluded from the trial. Later such infants were included in the trial but the sodium bicarbonate was added to the milk.

Most of the babies were divided by random selection, using sealed envelopes, into three groups, receiving respectively: (1) expressed breast milk, (2) SMA-S26, and (3) half-cream Regal milk. Being anxious not to discourage breast-feeding, however, we advised mothers who wished to breast-feed to express their milk, and their babies were included in group 1 . As a result group 1 was larger than the other two. Fifty-six

- No longer available. 
infants completed the trial: 26 in group 1, 16 in group 2, and 14 in group 3. Seven infants were withdrawn from the trial (Table I) and three died during the trial.

TABLE I-Reason for Withdrawal from Trial of Seven Infants

\begin{tabular}{c|l|c}
\hline Case No. & \multicolumn{1}{|c}{ Reason for Stopping Trial } & Type of Feed \\
\hline 1 & Respiratory distress syndrome & Expressed breast milk \\
2 & Septicaemia & SMA-S26 \\
3 & Respiratory distress syndrome & SMA-S26 \\
4 & Vomiting (6th day) & SMA-S26 \\
5 & Vomiting (10th day) & Expressed breast milk \\
6 & Mother took baby out of hospital & Half-cream Regal \\
7 & Mother wanted to breast-feed & \\
\hline
\end{tabular}

A feeding tube was passed through the nose into the stomach by a trained midwife normally to a distance of $20 \mathrm{~cm}$, but the measurement from the nose to the lower end of the sternum was always checked. Fluid was aspirated with a syringe, and if this was colourless and acid to litmus the tube was taped securely to the cheek with adhesive plaster. If bile-stained fluid was obtained the tube was withdrawn $2 \mathrm{~cm}$ and aspiration repeated. Aspiration was performed at least three times each day and the tube was changed every third day. For infants weighing $1,500 \mathrm{~g}$ or more the 4.5 F.G. polyvinyl chloride tube (Warne) was used, but for smaller infants the 3.5 F.G. polyvinyl chloride tube (Argyle) was preferred. Water was given at 2 hours and milk was introduced at $\mathbf{4}$ hours.

The milk was placed in an autoclaved intravenous infusion bottle which was connected to a paediatric disposable giving set. Initially, the Baxter BS1 set was used and proved satisfactory, but this was subsequently replaced by the Abbott giving set No. 4594 because the latter included a measuring chamber and it was thought that this would make it safer. The giving set was attached to the feeding tube and the bottle was suspended about $1 \mathrm{~m}$ above the infant. The bottle was changed every 8 hours and the giving set every 24 hours.

Each of the three milk feeds had the same energy value (65 calories $(272 \mathrm{~kJ}) / 100 \mathrm{ml})$. The protein content of human milk is $1.2 \mathrm{~g} / 100 \mathrm{ml}$, that of SMA-S26 $1.5 \mathrm{~g} / 100 \mathrm{ml}$, and that of halfcream Regal milk $4.1 \mathrm{~g} / 100 \mathrm{ml}$. Each type of feed was administered at exactly the same rate, starting with $60 \mathrm{ml} / \mathrm{kg} / 24 \mathrm{hr}$ on the first day and increasing the volume by daily increments of $30 \mathrm{ml} / \mathrm{kg}$ until the maximum of $300 \mathrm{ml} / \mathrm{kg} / 24 \mathrm{hr}$ was reached on the ninth day. Thereafter, feeds were adjusted according to the relative increase in body weight every third day.

The infants were nursed naked in incubators until they reached $2,000 \mathrm{~g}$, but the smallest babies needed an additional Perspex heat shield. The incubator temperature was adjusted to keep the rectal temperature between $36^{\circ} \mathrm{C}$ and $37 \cdot 2^{\circ} \mathrm{C}$. Thus the incubator temperature varied with the birth weight and age of the infant, but it was usually between $32 \cdot 2$ and $34.5^{\circ} \mathrm{C}$. In each incubator a firm mattress was covered by two thicknesses of absorbent paper towelling, and on it the baby was nursed prone, usually with the head higher than the feet. In this way regurgitation was reduced to a minimum and, when it did occur, the milk was spilled from the mouth without any danger of aspiration into the lungs.

The blood glucose level was estimated towards the end of the first 24 hours of life by a glucose oxidase method (normal $>20 \mathrm{mg} / 100 \mathrm{ml}$ ). In a few cases a preliminary Dextrostix test indicated a high level of glucose and a laboratory estimation was therefore omitted. The plasma calcium level was estimated by the method of Bachra et al. (1958) on the seventh day in most infants (normal 7-11 mg/100 ml). Blood for plasma calcium estimation was taken from a superficial antecubital vein and for blood glucose from a heel-prick. Serum bilirubin estimation was carried out whenever the Gosset icterometer (Gosset, 1960) indicated a level of $15 \mathrm{mg} / 100 \mathrm{ml}$ or above, and if this was confirmed phototherapy was used but no phenobarbitone was given.

The menstrual age was accepted as the gestational age, but the assessed age (Robinson, 1966) was used whenever the menstrual history was unreliable or when the menstrual age differed markedly from the assessed age.

Infants with a birth weight below the tenth centile for gestational age were regarded as light for dates. The standards used were those for singletons from the National Birthday Trust's perinatal mortality survey of 1958 supplemented by the Baltimore data (Gruenwald, 1966) at the lowest gestational ages.

\section{Results}

The birth weights and gestational ages of the three groups of infants were similar, as shown in Tables II and III.

TABLE II-Mean Birth Weights of the Three Groups of Infants

\begin{tabular}{|c|c|c|c|c|c|c|}
\hline & \multicolumn{2}{|c|}{ Group 1} & \multicolumn{2}{|c|}{ Group 2} & \multicolumn{2}{|c|}{ Group 3} \\
\hline & $\begin{array}{l}\text { No. of } \\
\text { Infants }\end{array}$ & $\begin{array}{c}\text { Birth } \\
\text { Weight }\end{array}$ & $\begin{array}{l}\text { No. of } \\
\text { Infants }\end{array}$ & $\begin{array}{c}\text { Birth } \\
\text { Weight }\end{array}$ & $\begin{array}{l}\text { No. of } \\
\text { Infants }\end{array}$ & $\underset{\text { Wirth }}{\text { Weight }}$ \\
\hline $\begin{array}{l}\text { Light for dates } \\
\text { Appropriate weight for } \\
\text { dates }\end{array}$ & $\begin{array}{l}12 \\
14\end{array}$ & $\begin{array}{r}1,842 \mathrm{~g} \\
1,759 \mathrm{~g}\end{array}$ & $\begin{array}{r}6 \\
10\end{array}$ & $\begin{array}{r}1,773 \mathrm{~g} \\
1,773 \mathrm{~g}\end{array}$ & $\begin{array}{l}7 \\
7\end{array}$ & $\begin{array}{l}1,853 \mathrm{~g} \\
1,804 \mathrm{~g}\end{array}$ \\
\hline
\end{tabular}

TABLE III-Gestational Age of the 56 Infants

\begin{tabular}{|c|c|c|c|c|c|}
\hline & & Group 1 & Group 2 & Group 3 & Total \\
\hline 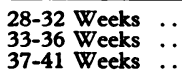 & $\begin{array}{l}\ldots \\
\therefore\end{array}$ & $\begin{array}{r}6 \\
15 \\
5\end{array}$ & $\begin{array}{r}3 \\
10 \\
3\end{array}$ & $\begin{array}{l}2 \\
8 \\
4\end{array}$ & $\begin{array}{l}11 \\
33 \\
12\end{array}$ \\
\hline
\end{tabular}

\section{SAFETY OF METHOD}

The safety of this method of feeding babies of low birth weight was confirmed; there was no clinical, radiological, or pathological evidence of aspiration of milk in any infant in the trial. There was no instance of symptomatic hypoglycaemia or hypocalcaemia, although one infant had a plasma calcium level of $6.0 \mathrm{mg} / 100 \mathrm{ml}$.

The mean blood glucose level at the end of the first 24 hours of life was 64.1 (range $20-167$ ) $\mathrm{mg} / 100 \mathrm{ml}$ in group $1,71.8$ (range $50-110$ ) $\mathrm{mg} / 100 \mathrm{ml}$ in group 2 , and 66.0 (range $38-96$ ) $\mathrm{mg} / 100 \mathrm{ml}$ in group 3 . The mean plasma calcium level on the seventh day of life was 10.0 (range $7 \cdot 3-11.3$ ) $\mathrm{mg} / 100 \mathrm{ml}$ in group $1,10.0$ (range $7.5-11.4$ ) $\mathrm{mg} / 100 \mathrm{ml}$ in group 2, and 9.4 (range $6 \cdot 0-11 \cdot 3$ ) $\mathrm{mg} / 100 \mathrm{ml}$ in group 3. The highest serum bilirubin level was $16.4 \mathrm{mg} / 100 \mathrm{ml}$ and no exchange transfusions were performed.

\section{BABIES WITHDRAWN FROM TRIAL}

Seven infants were withdrawn from the trial for the reasons indicated in Table I. The persistent vomiting in two infants stopped immediately the volume of the feed was reduced, but despite the vomiting there was no evidence of aspiration.

\section{INFANT DEATHS DURING TRIAL}

During the period of the trial three infants died who had received milk by intragastric drip. There was no clinical evidence that death was in any way related to the method of feeding. Necropsy was performed by a paediatric pathologist on two of these babies, but neither showed evidence of aspiration of milk.

Case 2.-Birth weight was 2,000 $\mathrm{g}$ and feeding with SMA-S26 was started. Progress was normal until the sixth day, when congestive cardiac failure occurred. In spite of ligation of a large patent ductus arteriosus the baby died. 
Case 8.-Birth weight was $1,360 \mathrm{~g}$ and gestational age 32 weeks. Feeding with expressed breast milk was started. The infant appeared normal for $\mathbf{4 8}$ hours, after which cyanosis developed and there were numerous apnoeic spells in spite of the administration of $100 \%$ oxygen; death occurred shortly afterwards. A Dextrostix test had shown no evidence of hypoglycaemia. Necropsy showed extensive primary atelectasis and aspiration of amniotic fluid. There was no evidence of aspiration of milk.

Case 9.-Birth weight was $1,800 \mathrm{~g}$ and gestational age 32 weeks. Grunting, rib recession, and raised respiratory rate were noted at 2 hours. Feeding with half-cream Regal milk was started at 4 hours. Eight hours later he developed severe respiratory distress syndrome, necessitating intermittent positive-pressure ventilation, but he died at the age of 16 hours. Consent for necropsy was refused for religious reasons.

\section{INFANTS EXCLUDED FROM TRIAI}

During the period of the trial 10 infants died whose birth weights were below the minimum accepted for inclusion in the trial. Thirteen infants developed severe signs of the respiratory distress syndrome before the first feed was given and were excluded from the trial because dextrose solution with bicarbonate was given instead of milk. One infant had an extensive myelomeningocoele and diaphragmatic hernia and was transferred for surgery immediately after birth.

\section{COMPLICATIONS}

One infant (birth weight $1,870 \mathrm{~g}$ ) receiving SMA-S26 vomited repeatedly on the third day. Thick curds were aspirated from the stomach and the trial was continued and completed normally. Another infant (birth weight, 2,040 g) receiving half cream Regal Milk vomited several times and had abdominal distension on the seventh day. Thick curds were aspirated from the stomach and the trial was continued and completed normally.

\section{WEIGHT CHANGE}

The weight changes during the first three weeks of the trial are shown in Tables IV and V. In the first week for all patients the weight gain on half-cream Regal milk (group 3) was significantly greater than on SMA-S26 (group 2$)(t=2 \cdot 71 ; 28$ D.F.).

TABLE IV-Weekly Weight Changes in Infants of Appropriate Weight for Dates

\begin{tabular}{|c|c|c|c|c|c|c|}
\hline & \multicolumn{2}{|c|}{ Group 1} & \multicolumn{2}{|c|}{ Group 2} & \multicolumn{2}{|c|}{ Group 3} \\
\hline & $\begin{array}{l}\text { No. of } \\
\text { Infants }\end{array}$ & $\begin{array}{c}\text { Mean } \\
\text { Change }\end{array}$ & $\begin{array}{l}\text { No. of } \\
\text { Infants }\end{array}$ & $\begin{array}{l}\text { Mean } \\
\text { Change }\end{array}$ & $\begin{array}{l}\text { No. of } \\
\text { Infants }\end{array}$ & $\begin{array}{c}\text { Mean } \\
\text { Change }\end{array}$ \\
\hline $\begin{array}{l}\text { First week } \\
\text { Second week } \ldots \\
\text { Third week } \ldots\end{array}$ & $\begin{array}{l}14 \\
14 \\
14\end{array}$ & $\begin{array}{r}-18 \mathrm{~g} \\
+143 \mathrm{~g} \\
+225 \mathrm{~g}\end{array}$ & $\begin{array}{l}10 \\
10 \\
10\end{array}$ & $\begin{array}{r}-37 \mathrm{~g} \\
+134 \mathrm{~g} \\
+263 \mathrm{~g}\end{array}$ & $\begin{array}{l}7 \\
7 \\
6\end{array}$ & $\begin{array}{l}+66 \mathrm{~g} \\
+260 \mathrm{~g} \\
+285 \mathrm{~g}\end{array}$ \\
\hline
\end{tabular}

TABLE v-Weekly Weight Gains in Infants of Light Weight for Dates

\begin{tabular}{l|c|c|c|c|c|c}
\hline & \multicolumn{2}{|c|}{ Group 1 } & \multicolumn{2}{c|}{ Group 2 } & \multicolumn{2}{c}{ Group 3 } \\
\cline { 2 - 7 } & $\begin{array}{c}\text { No. of } \\
\text { Infants }\end{array}$ & $\begin{array}{c}\text { Mean } \\
\text { Change }\end{array}$ & $\begin{array}{c}\text { No. of } \\
\text { Infants }\end{array}$ & $\begin{array}{c}\text { Mean } \\
\text { Change }\end{array}$ & $\begin{array}{c}\text { No. of } \\
\text { Infants }\end{array}$ & $\begin{array}{c}\text { Mean } \\
\text { Change }\end{array}$ \\
\hline $\begin{array}{l}\text { First week } \\
\text { Second week } . .\end{array}$ & 12 & $+37 \mathrm{~g}$ & 6 & $\mathbf{6} \mathrm{g}$ & 7 & $+152 \mathrm{~g}$ \\
Third week.. & 11 & $+214 \mathrm{~g}$ & 6 & $+208 \mathrm{~g}$ & 3 & $+220 \mathrm{~g}$ \\
$+234 \mathrm{~g}$ & 6 & $+267 \mathrm{~g}$ & 2 & $+314 \mathrm{~g}$ \\
\hline
\end{tabular}

The weight gain on half-cream Regal milk was significantly greater than on SMA-S26 in the infants of appropriate weight for dates in the second week $(t=2.32 ; 15$ D.F.).

The total weight gains from birth to 6 weeks were similar in the three groups. The numbers remaining in the trial at 6 weeks, however, were small for a variety of reasons.

\section{Discussion}

\section{COMPLICATIONS OF LARGE-VOLUME DRIP FEEDING}

Death from massive aspiration of a feed and pneumonia secondary to small aspirations are the chief hazards in feeding small infants. Neither of these complications occurred in this series.

Persistent vomiting with abdominal distension occurred in four infants. In two of them, weighing about $1,500 \mathrm{~g}$ and receiving SMA-S26, the volume of the feed had to be reduced on the sixth and tenth days respectively and the trial was stopped. In the other two infants, receiving SMA-S26 and half-cream Regal milk respectively, thick curds were aspirated from the stomach and the trial was continued. The mechanism for this vomiting is uncertain but it occurred only with the cows' milk preparations, in which the curds are known to be larger than in human milk, and may have been due to obstruction of the pylorus from curds. Plain radiographs of the abdomen in these infants showed dilatation of the stomach but no small-gut distension or fluid levels, and all recovered without surgery. It is possible that the two infants whose feeds had to be reduced would have developed obstruction from the "milk-plug syndrome" which has been observed with all milk preparations, although rarely with human milk (V. A. J. Swain, personal communication, 1971). Although this syndrome has been recognized only in the past few years and this has coincided with the use of feeds of larger volume for infants of low birth weight, there is little published evidence that the patients developing the syndrome have received larger volumes than those previously accepted as conventional (Cook and Rickham, 1969).

Hypocalcaemia might have been expected, especially in the infants given half-cream Regal milk, who received high fat and phosphate loads, either or both of which were considered important hypocalcaemic factors in previous studies of full-term infants (Widdowson, 1969; Barltrop and Oppé, 1970). No infant in this trial, however, had clinical signs of hypocalcaemia, and only one (on half-cream Regal milk) had a serum calcium level below $7 \mathrm{mg} / 100 \mathrm{ml}$.

The single blood glucose estimations at 24 hours of life were within the normal range in all infants. Since a continuous high energy intake was maintained it was thought most unlikely that there would have been any asymptomatic hypoglycaemia in these infants, particularly in view of other workers' experience of early adequate feeding of infants of low birth weight (Smallpeice and Davies, 1964). Certainly none of the babies in the trial developed symptomatic hypoglycaemia.

Towards the end of the trial, when the use of the Guthrie test was started in the unit, it was noted that in infants receiving half-cream Regal milk, which had the highest protein content, there was a high incidence of positive results on the seventh day. Detailed plasma amino-acid estimations showed that high levels of some amino-acids were present only in those infants who were receiving half-cream Regal milk. Although the significance of this finding is unknown and has been discussed in detail elsewhere (Valman et al., 1971), the levels of amino-acids in the plasma were sometimes so high that it was thought unwise to continue using half-cream Regal milk in these large volumes, and thereafter the trial was continued with expressed breast milk and SMA-S26 only.

Large feeds have the theoretical possibility of imprinting a pattern of feeding which will result in later obesity. At the first outpatient visit, two weeks after discharge, these patients' intakes had fallen to conventional volumes. Indeed, Combes and Pratt (1961) showed that infants of low birth weight receiving double-strength feeds in the neonatal period and gaining $42 \mathrm{~g}$ / day had the same average weight at 6 months of age as those receiving single-strength feeds and gaining $32 \mathrm{~g} /$ day.

\section{ADVANTAGES OF LARGE-VOLUME DRIP FEEDING}

The importance of early feeding in preventing brain damage due to hypoglycaemia has been accepted (Laurence and Smith, 
1962; Drillien, 1964; Smallpeice and Davies, 1964). Our methods seem to prevent symptomatic hypoglycaemia without the need for repeated laboratory monitoring of the blood glucose level.

The reason for maintaining very large energy intakes was to prevent an interruption in brain growth with consequent possible permanent reduction in brain capacity (Dobbing, 1968). During drip feeding the reduction in handling of the small infants lowers the risk of cross-infection, diminishes the loss of energy due to cooling, and saves valuable nursing time. Feeding the smallest infants is the most time-consuming task of the staff of a special care unit, producing considerable tension at times, especially when staff is depleted. There were no insuperable difficulties in managing this trial in spite of several changes in nursing staff. Our unit is staffed mainly by pupil midwives, as in many other district hospitals, and these methods have been dictated by necessity as well as providing better medical care.

\section{COMPARISON OF MILKS}

Although this trial was designed to determine the physical and biochemical safety of large volume intakes, the differences in weight gains between the different groups are of interest. The weight gains on human and SMA-S26 milk were similar throughout the trial period. In the first week for all patients the weight gain on half-cream Regal milk was significantly greater than on SMA-26 (Tables IV and V). The infants in the half-cream Regal group received the highest mineral load, and this may have been responsible for the larger weight gains in the first two weeks, although Davidson et al. (1967) showed that variations in the mineral content of feeds over a wide range had no effect on weight gains.

It has been traditional for many years to follow the dictum of Levine (Gordon et al., 1947) that breast milk is inadequate for babies of low birth weight. Hence a valuable link between mother and infant in the early days is denied to many of these infants all over the world, with a grave risk of rejection or even child abuse. In our unit mothers are encouraged to provide breast milk for their infants and have been grateful for the satisfaction of feeling that they are playing a vital part in the care of their infants. In fact, there is a high incidence of established breast-feeding of babies of low birth weight in our unit.

The results of this trial show that human milk is an adequate food for infants of low birth weight provided that a sufficient daily intake is maintained. SMA-S26 has been shown to be a safe and satisfactory milk feed if breast milk is not available. How- ever, our experience suggests that half-cream cows' milk preparations in these large volumes cannot be recommended unreservedly as a safe alternative.

We thank Miss M. A. Woodward, superintendent midwife, and Sisters J. Ryans and J. Burley, who were in charge of the special care unit and without whose valuable co-operation this study could not have been completed. We are indebted to Michael Curwen for advice on planning this study and to Mr. G. L. Draper of the department of social medicine, Oxford University, for help with the statistical analysis. We thank Dr. N. E. France for the postmortem examinations and Miss $T$. Cotgrove and Dr. B. Levin for the biochemical estimations. We are indebted to John Wyeth and Brother Ltd. for defraying part of the cost of the investigation.

Requests for reprints should be addressed to: $\mathrm{Dr}$. H. B. Valman, Northwick Park Hospital, Harrow, Middlesex HA1 3UJ.

\section{References}

Babson, S. G. (1970). Fournal of Pediatrics, 77, 11

Bachra, B. N., Dauer, A., and Sobel, A. E. (1958). Clinical Chemistry, 4, 107 Barltrop, D., and Oppé, T. E. (1970). Lancet, 2, 1333.

Barltrop, D., and Oppe, T. E. (1970). Lancet, 2, 1333. 163

Combes, M. A., and Pratt, E. L. (1961). American fournal of Diseases of Children, 102, 610 .

Cook, R. C. M., and Rickham, P. P. (1969). Fournal of Pediatric Surgery, 4

Daily, W. J. R., Klaus, M., and Meyer, H. B. P. (1969). Pediatrics, 43, 510 Davidson, M., Levine, S. Z., Bauer, C. H., and Dann, M. (1967). Fournal of Pediatrics, 70, 695

Davies, P. A., and Russell, H. (1968). Developmental Medicine and Child Neurology, 10, 725 .

Day, R. L., Caliguiri, L., Kamenski, C., and Ehrlich, F. (1964). Pediatrics, $34,171$.

Dobbing, J. (1968). In Applied Neurochemistry, ed. A. N. Davison and J. Dobbing, p. 287. London, Oxford University Press.

Drillien, C. M. (1964). Growth and Development of the Prematurely Borm Infant, p. 304 . Edinburgh, Livingstone.

Gordon, H. H., Levine, S. Z., and McNamara, H. (1947). American fournal of Diseases of Children, 73, 442 .

Gosset, I. H. (1960). Lancet, 1, 87.

Gruenwald, P. M. (1966). American fournal of Obstetrics and Gynecology, 94, 1112.

Hey, E. N., and Katz, G. (1970). Archives of Disease in Childhood, 45, 328.

Laurence, B. M., and Smith, B. H. (1962). Lancet, 1, 589.

Robinson, R. J. (1966). Archives of Disease in Childhood, 41, 437

Scopes, J. W., and Ahmed, I. (1966). Archives of Disease in Childhood, 41, 407.

Smallpeice, V., and Davies, P. A. (1964). Lancet, 2, 1349.

Valman, H. B., Brown, R. J. K., Palmer, T., Oberholzer, V. G., and Levin, B (1971). British Medical fournal, 4,789 .

Widdowson, E. M. (1969). Fournal of the Royal College of Physicians of

Young, W. F., Poyner-Wall, P., Humphreys, H. C., Finch, E., and Broadbent, I. (1950). Archives of Disease in Childhood, 25, 31 .

bent, I. (1950). Archives of Disease in Childhood, 25, 31.
Ziegler, E. E., and Fomon, S. J. (1971). Fournal of Pediatrics, 78, 561.

\section{Crohn's Disease and Pregnancy}

\section{F. T. DE DOMBAL, I. L. BURTON, J. C. GOLIGHER}

\section{British Medical fournal, 1972, 3, 550-553}

\section{Summary}

This paper reports the outcome of 60 pregnancies in 40 women, all of whom had concomitant Crohn's disease. Detailed analysis of pregnancy rates in Crohn's disease supports in outline the hypothesis that some patients with bowel symptoms may be rendered temporarily subfertile by the activity of their bowel complaints. In contrast there is little or no evidence of any adverse

University Department of Surgery, General Infirmary, Leeds

F. T. DE DOMBAL, M.D., F.R.C.S., Reader in Clinical Information Science I. L. BURTON, M.B., CH.B., Research Assistant

J. C. GOLIGHER, CH.M., F.R.C.S., Professor of Surgery effect during pregnancy on mother or child. Most pregnancies went normally to term and, if anything, Crohn's disease tended to improve during the period of confinement.

After delivery, however, over $40 \%$ of patients suffered a relapse of Crohn's disease. Such a situation might well constitute a logical indication for the administration of corticosteroid therapy.

\section{Introduction}

Numerous authors have suggested that the occurrence of an inflammatory bowel disorder and pregnancy in the same patient carries an extremely unfavourable prognosis (Barnes and Hayes, 1931; Blair and Allen, 1962; Boreham and Saltau, 